\title{
RESPONSE OF RICE GROWN IN SALINE SOIL AS INFLUENCED BY THE APPLICATION OF AGRICULTURAL AMENDMENTS AND MOISTURE REGIMES
}

\author{
Akter, S., H. R. Khan, M. S. Hossain, M. K. Saha and F. Farzana \\ Department of Soil, Water and Environment, University of Dhaka, Dhaka 1000, Bangladesh
}

\begin{abstract}
The experiment was carried out with rice (BRRI dhan48) grown in saline soil at the premises of the Department of Soil, Water and Environment, University of Dhaka to evaluate the impacts of agricultural amendments, such as rice hull (RH), rice straw (RS) and sawdust (SD) each applied at the rates of 0,4 and $8 \mathrm{t} \mathrm{ha}^{-1}$ in moist (80\% moisture) and saturated soil conditions. Most of the growth and yield components of rice were found to increase significantly $(p \leq 0.05)$ with the increased rates regardless of kinds of organic treatments under both the moisture levels. The tallest plant heights ( $99 \mathrm{~cm}$ in moist, $105 \mathrm{~cm}$ in saturated condition) were recorded at maturity stage of rice with the $\mathrm{RH}_{8} \mathrm{RS}_{8} \mathrm{SD}_{8}$ treatment, which received the highest rates of these three organic amendments. The shortest plant heights $(79 \mathrm{~cm}$ in moist; $86 \mathrm{~cm}$ in saturated conditions) were recorded in control pot $\left(\mathrm{RH}_{0} \mathrm{RS}_{0} \mathrm{SD}_{0}\right)$, where no amendment was made. The maximum numbers of tillers were observed in $\mathrm{RH}_{8} \mathrm{RS}_{8} \mathrm{SD}_{8}$ followed by $\mathrm{RH}_{8} \mathrm{RS}_{8} \mathrm{SD}_{4}, \mathrm{RH}_{8} \mathrm{RS}_{4} \mathrm{SD}_{8}, \mathrm{RH}_{4} \mathrm{RS}_{8} \mathrm{SD}_{8}$ and $\mathrm{RH}_{4} \mathrm{RS}_{4} \mathrm{SD}_{8}$ treatments at saturated condition. The straw dry matter and grain yields of rice were also found to vary significantly $(\mathrm{p} \leq 0.05)$ by the individual application of rice hull, rice straw, sawdust and moisture conditions, but their combined effects were found to be highly significant at their higher doses of combination. The highest grain yield $\left(4.4 \mathrm{t} \mathrm{ha}^{-1}\right)$ was recorded in $\mathrm{RH}_{8} \mathrm{RS}_{8} \mathrm{SD}_{8}$ treatment followed by $\mathrm{RH}_{8} \mathrm{RS}_{8} \mathrm{SD}_{4}\left(4.2 \mathrm{th} \mathrm{ha}^{-1}\right)$ and $\mathrm{RH}_{8} \mathrm{RS}_{4} \mathrm{SD}_{8}\left(4.1 \mathrm{t} \mathrm{ha}^{-1}\right)$ at saturated condition. Harvest index and 1000 grain weight of the rice were attained positive under both the moisture conditions, but at saturated condition of the soil, the amendments (RH, RS and SD) produced better response for these components compared to those of the moist soil condition.
\end{abstract}

Key words: Yield components, rice hull, rice straw, sawdust, saline soil, harvest index

\section{INTRODUCTION}

Strenuous efforts are made world-wide to grow more food and extend the acreage under crop production for feeding the projected increase of population that could reach a total of ten billion by the $21^{\text {st }}$ century. World Resource Institute and FAO advocated increasing food production by $40-50 \%$ of the current level to feed the hungry mouths. But, the availability of land for growing crops is limited; it may become inevitable to utilize marginal and problem soils or to improve the yield potential for crops per unit land under various soil stresses (Khan et al. 2016).

Adequate rice (Oryza sativa L.) production resembles rice security which is the key to ensure food security in Bangladesh (Kabir et al. 2015). Extensive use of inorganic fertilizers not only degrade soil physicochemical properties along with soil organic matter depletion (Ali et al. 2009), but also unable to sustain desired yield goal. A good supply of OM is essential for sustaining soil fertility and crop productivity, although organic manures alone cannot ensure sustainable rice production. Therefore, the uses of organic and inorganic sources in an integrated approach is the best management practices for sustaining soil health and crop productivity (Sarkar et al. 2016) under different agro-ecological zones of Bangladesh.

Rice straw production is plenty in Bangladesh, but its removal from the field resulting a great loss of nutrients from the soils. Use of rice straw in paddy soil not only improve organic $\mathrm{C}, \mathrm{N}$, and available $\mathrm{P}, \mathrm{K}$, and $\mathrm{Si}$ (Ponnamperuma1984), but also show more than one ton per hectare yield 
advantage of Boro rice (Saha et al.2009). Rice hull as a residue after paddy harvest may be another important agricultural material for paddy rice production. Similarly sawdust as a wooden residue is important in terms of recycling to agricultural lands, as well as, ensuring sustainability of soil fertility through the improvement of nutrient status in soil and also contributing to rice production by improving physical and chemical properties of soils. Rice straw contains numerous elements essential for plant growth, including nitrogen, phosphorus, potassium, sulfur and calcium (Gaihre et al. 2013). Approximately $40 \%$ of $\mathrm{N}, 30$ to $35 \%$ of $\mathrm{P}, 80-85 \%$ of $\mathrm{K}$, and $40-45 \%$ of $\mathrm{S}$ taken up by rice remain in the straw at crop maturity (Dobermann and Fairhurst 2002). It also contains different biopolymers, such as cellulose (32-37\%), hemicelluloses (29-37\%), and lignin (5-15\%) (Conrad 2002). These nutrients are released to soil through mineralization processes and are, therefore, available for subsequent crop growth (Byous et al. 2004). Therefore, the present study was carried out to evaluate the potentials of rice hull, rice straw and sawdust application on the growth and yield components of rice grown in saline soil.

\section{MATERIAL AND METHODS}

The pot experiment was conducted in the net house of the Department of Soil, Water and Environment, University of Dhaka, from May to August, 2017 to analyze the potentials of different agricultural amendments on the growth and yield components of rice plants grown in saline soil. The rice variety BRRI dhan 48 was used as the test crop. The soil used in the experiment was collected from Kalapara Upazila of Patuakhali district. Some selected properties of initial soil were determined following standard methods (Table 1).

Table 1. Physico-chemical properties of initial soil on oven dry basis.

\begin{tabular}{|c|c|}
\hline Properties & Values \\
\hline Particle density $\left(\mathrm{g} \mathrm{cm}^{-3}\right)$ & 2.53 \\
\hline Bulk density $\left(\mathrm{g} \mathrm{cm}^{-3}\right)$ & 1.37 \\
\hline Porosity (\%) & 45.81 \\
\hline Moisture content (\%; Black 1965) & 3.31 \\
\hline Textural class (Hydrometer method; Piper 1966) & Clay loam \\
\hline pH (1:2.5; Jackson 1973) & 6.90 \\
\hline EC (dS m${ }^{-1} ;$ Saturation extract, Richards 1954) & 3.96 \\
\hline Organic carbon $\left(\mathrm{g} \mathrm{kg}^{-1}\right.$; Nelson and Sommers 1982) & 7.80 \\
\hline Total Nitrogen ( $\mathrm{g} \mathrm{kg}^{-1}$; Jackson 1973) & 0.60 \\
\hline Available Nitrogen ( $\mathrm{mg} \mathrm{kg}^{-1} ; 1 \mathrm{~N} \mathrm{KCl}$; Jackson 1973) & 54.55 \\
\hline Available Phosphorus ( $\mathrm{mg} \mathrm{kg}^{-1}$; Olsen et al. 1954) & 12.58 \\
\hline Available Potassium $\left(\mathrm{mg} \mathrm{kg}^{-1}\right.$; Pratt 1965) & 25.00 \\
\hline Cation Exchange Capacity (c mol kg-1 ; Chapman 1965) & 18.67 \\
\hline Sodium Adsorption Ratio (Richards 1954) & 7.72 \\
\hline Exchangeable Sodium Percentage (Richards 1954) & 20.92 \\
\hline \multicolumn{2}{|l|}{ Exchangeable Cations (c mol kg-1; 1 N CH${ }_{3} \mathrm{COONH}_{4}$ ) } \\
\hline Sodium (flame photometer) & 3.91 \\
\hline Potassium (flame photometer) & 0.64 \\
\hline Calcium (AAS*) & 1.87 \\
\hline Magnesium (AAS*) & 3.26 \\
\hline \multicolumn{2}{|l|}{ Water Soluble Anions $\left(\mathrm{c} \mathrm{mol} \mathrm{kg}^{-1}\right)$} \\
\hline Chloride (0.005 N AgNO 3 ; Jackson 1973) & 2.87 \\
\hline Sulphate $\left(\mathrm{BaCl}_{2} ;\right.$ Jackson 1973$)$ & 1.45 \\
\hline Bicarbonate $\left(0.05 \mathrm{~N} \mathrm{H}_{2} \mathrm{SO}_{4}\right.$; Richards 1954) & 0.47 \\
\hline Carbonate $\left(0.05 \mathrm{~N} \mathrm{H}_{2} \mathrm{SO}_{4}\right.$; Richards 1954) & ND* \\
\hline
\end{tabular}

ND*= Not in detectable range, $\mathrm{AAS}^{*}=$ Atomic Absorption Spectrophotometer. 
Rice Hull (RH), Rice Straw (RS) and Sawdust (SD) were used as agricultural amendments for the soil studied. The experiment was conducted with Rice Hull $\times$ Rice Straw $\times$ Sawdust each at 3 rates having 3 replications under 2 moisture levels (moist: 80\% moisture and saturated: $>100 \%$ moisture). Total number of treatments was 27 (for each moisture levels; Table 2). Basal doses of N, P and K were applied at the rates of 120,60 and $80 \mathrm{~kg} \mathrm{ha}^{-1}$ as Urea, TSP and MoP, respectively. The whole TSP, MoP and half of the urea were applied during soil preparation. The remaining urea was top dressed in two splits, at active tillering and panicle initiation stage.

Table 2. Treatment combinations for each set (moist and saturated) of the experiment.

\begin{tabular}{|c|c|c|c|c|}
\hline \multicolumn{2}{|r|}{ Treatment } & \multicolumn{3}{|c|}{ Rate $\left(\mathrm{t}\right.$ ha $\left.^{-1}\right)$ : moist and saturated soil conditions } \\
\hline No. & Denotation & Rice Hull (RH) & Rice Straw (RS) & Sawdust (SD) \\
\hline $\mathrm{T}_{1}$ & $\mathrm{RH}_{0} \mathrm{RS}_{0} \mathrm{SD}_{0}$ & 0 & 0 & 0 \\
\hline $\mathrm{T}_{2}$ & $\mathrm{RH}_{0} \mathrm{RS}_{0} \mathrm{SD}_{4}$ & 0 & 0 & 4 \\
\hline $\mathrm{T}_{3}$ & $\mathrm{RH}_{0} \mathrm{RS}_{0} \mathrm{SD}_{8}$ & 0 & 0 & 8 \\
\hline $\mathrm{T}_{4}$ & $\mathrm{RH}_{0} \mathrm{RS}_{4} \mathrm{SD}_{0}$ & 0 & 4 & 0 \\
\hline $\mathrm{T}_{5}$ & $\mathrm{RH}_{0} \mathrm{RS}_{4} \mathrm{SD}_{4}$ & 0 & 4 & 4 \\
\hline $\mathrm{T}_{6}$ & $\mathrm{RH}_{0} \mathrm{RS}_{4} \mathrm{SD}_{8}$ & 0 & 4 & 8 \\
\hline $\mathrm{T}_{7}$ & $\mathrm{RH}_{0} \mathrm{RS}_{8} \mathrm{SD}_{0}$ & 0 & 8 & 0 \\
\hline $\mathrm{T}_{8}$ & $\mathrm{RH}_{0} \mathrm{RS}_{8} \mathrm{SD}_{4}$ & 0 & 8 & 4 \\
\hline $\mathrm{T}_{9}$ & $\mathrm{RH}_{0} \mathrm{RS}_{8} \mathrm{SD}_{8}$ & 0 & 8 & 8 \\
\hline $\mathrm{T}_{10}$ & $\mathrm{RH}_{4} \mathrm{RS}_{0} \mathrm{SD}_{0}$ & 4 & 0 & 0 \\
\hline $\mathrm{T}_{11}$ & $\mathrm{RH}_{4} \mathrm{RS}_{0} \mathrm{SD}_{4}$ & 4 & 0 & 8 \\
\hline $\mathrm{T}_{12}$ & $\mathrm{RH}_{4} \mathrm{RS}_{0} \mathrm{SD}_{8}$ & 4 & 0 & 8 \\
\hline $\mathrm{T}_{13}$ & $\mathrm{RH}_{4} \mathrm{RS}_{4} \mathrm{SD}_{0}$ & 4 & 4 & 0 \\
\hline $\mathrm{T}_{14}$ & $\mathrm{RH}_{4} \mathrm{RS}_{4} \mathrm{SD}_{4}$ & 4 & 4 & 4 \\
\hline $\mathrm{T}_{15}$ & $\mathrm{RH}_{4} \mathrm{RS}_{4} \mathrm{SD}_{8}$ & 4 & 4 & 8 \\
\hline $\mathrm{T}_{16}$ & $\mathrm{RH}_{4} \mathrm{RS}_{8} \mathrm{SD}_{0}$ & 4 & 8 & 0 \\
\hline $\mathrm{T}_{17}$ & $\mathrm{RH}_{4} \mathrm{RS}_{8} \mathrm{SD}_{4}$ & 4 & 8 & 4 \\
\hline $\mathrm{T}_{18}$ & $\mathrm{RH}_{4} \mathrm{RS}_{8} \mathrm{SD}_{8}$ & 4 & 8 & 8 \\
\hline $\mathrm{T}_{19}$ & $\mathrm{RH}_{8} \mathrm{RS}_{0} \mathrm{SD}_{0}$ & 8 & 0 & 0 \\
\hline $\mathrm{T}_{20}$ & $\mathrm{RH}_{8} \mathrm{RS}_{0} \mathrm{SD}_{4}$ & 8 & 0 & 4 \\
\hline $\mathrm{T}_{21}$ & $\mathrm{RH}_{8} \mathrm{RS}_{0} \mathrm{SD}_{8}$ & 8 & 0 & 8 \\
\hline $\mathrm{T}_{22}$ & $\mathrm{RH}_{8} \mathrm{RS}_{4} \mathrm{SD}_{0}$ & 8 & 4 & 0 \\
\hline $\mathrm{T}_{23}$ & $\mathrm{RH}_{8} \mathrm{RS}_{4} \mathrm{SD}_{4}$ & 8 & 4 & 4 \\
\hline $\mathrm{T}_{24}$ & $\mathrm{RH}_{8} \mathrm{RS}_{4} \mathrm{SD}_{8}$ & 8 & 4 & 8 \\
\hline $\mathrm{T}_{25}$ & $\mathrm{RH}_{8} \mathrm{RS}_{8} \mathrm{SD}_{0}$ & 8 & 8 & 0 \\
\hline $\mathrm{T}_{26}$ & $\mathrm{RH}_{8} \mathrm{RS}_{8} \mathrm{SD}_{4}$ & 8 & 8 & 4 \\
\hline $\mathrm{T}_{27}$ & $\mathrm{RH}_{8} \mathrm{RS}_{8} \mathrm{SD}_{8}$ & 8 & 8 & 8 \\
\hline
\end{tabular}

Seedlings were collected through the courtesy of BRRI (Bangladesh Rice Research Institute), Joydebpur, Gazipur. Twenty five days-old seedlings of BRRI dhan 48 were transplanted at the rate of 3 seedlings per hill and 3 hills in each pot by arranging in a triangular grid.

In the case of moist condition, $80 \%$ water content seemed to be reasonable for the survival of rice plant and did not allow standing water. But in the case of saturated condition, more than $100 \%$ water was maintained during irrigation throughout the growing period. Intercultural operations were performed when required.

Plant height, tiller, straw yields, grain yields, harvest index and 1000 grain weight were recorded after the harvest of crop at maturity. The significance of different treatments was analyzed by Duncan's New Multiple Range Test (DMRT). 
Plant height

\section{RESULTS AND DISCUSSION}

Plant height of the rice was found to be increased with the application of rice hull, rice straw and saw dust under both the moisture levels. The increment of plant height by different treatments over control ranged between 2.53 and 8.86 , and 1.16 and $8.14 \%$ at moist and saturated conditions, respectively. The present results are also noticed that the increments were more pronounced with the higher rates of application of the indigenous agricultural amendments like rice hull, rice straw and saw dust which might be due to the improvement of soil fertility as well as maintenance of favorable soil physical and chemical conditions for plant growth resulting an improvement in plant heights (Table 3).

Table 3. Comparison of plant heights (cm) of rice (BRRI dhan 48) grown in saline soil as influenced by the application of rice hull (RH), rice straw (RS), saw dust (SD) and moisture conditions.

\begin{tabular}{|c|c|c|c|c|c|c|c|}
\hline \multicolumn{8}{|c|}{ Moist condition (about $80 \%$ field moisture was maintained through irrigation) } \\
\hline \multirow{2}{*}{\multicolumn{2}{|c|}{$\mathbf{R H} \times \mathbf{R S} \times \mathbf{S D}$}} & \multirow{3}{*}{ 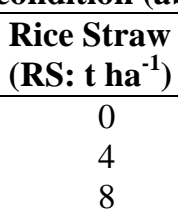 } & \multicolumn{3}{|c|}{ Sawdust (SD: ha $^{-1}$ ) } & \multirow{2}{*}{ RH mean } & \multirow[t]{2}{*}{ RS mean } \\
\hline & & & $\mathbf{0}$ & 4 & 8 & & \\
\hline \multirow{3}{*}{ 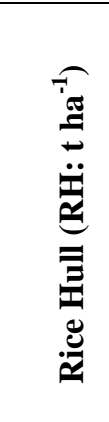 } & 0 & & $\begin{array}{c}79 \\
85 \mathrm{ad} \\
89 \mathrm{fg}\end{array}$ & $\begin{array}{c}81 \\
84 \mathrm{ad} \\
86 \mathrm{bc}\end{array}$ & $\begin{array}{l}84 \mathrm{ad} \\
84 \mathrm{ad} \\
88 \mathrm{ef}\end{array}$ & 84.44 & $\begin{array}{c}84.22 \\
\left(0 \mathrm{t} \mathrm{ha}^{-1}\right)\end{array}$ \\
\hline & 4 & $\begin{array}{l}0 \\
4 \\
8\end{array}$ & $\begin{array}{c}83 \mathrm{~d} \\
85 \mathrm{ab} \\
85 \mathrm{ab}\end{array}$ & $\begin{array}{l}85 \mathrm{ab} \\
89 \mathrm{fg} \\
91 \mathrm{hi}\end{array}$ & $\begin{array}{c}86 \mathrm{bc} \\
90 \mathrm{gh} \\
92 \mathrm{i}\end{array}$ & 87.33 & $\begin{array}{c}88.22 \\
\left(4 \mathrm{tha}^{-1}\right)\end{array}$ \\
\hline & 8 & $\begin{array}{l}0 \\
4 \\
8\end{array}$ & $\begin{array}{l}85 \mathrm{ab} \\
86 \mathrm{bc} \\
87 \mathrm{ce}\end{array}$ & $\begin{array}{c}87 \mathrm{ce} \\
94 \mathrm{ij} \\
97 \mathrm{j}\end{array}$ & $\begin{array}{c}88 \text { ef } \\
97 \mathrm{j} \\
99 \mathrm{j}\end{array}$ & 91.11 & $\begin{array}{c}90.44 \\
\left(8 \mathrm{t} \mathrm{ha}^{-1}\right)\end{array}$ \\
\hline \multicolumn{7}{|c|}{ Sawdust (SD) mean } & \\
\hline \multicolumn{8}{|c|}{ Saturated condition (about $2-3 \mathrm{~cm}$ standing water was maintained through irrigation) } \\
\hline \multirow{3}{*}{ 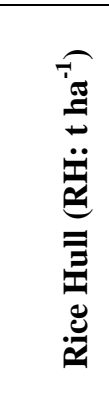 } & 0 & $\begin{array}{l}0 \\
4 \\
8\end{array}$ & $\begin{array}{c}86 \mathrm{~d} \\
87 \mathrm{de} \\
88 \mathrm{e}\end{array}$ & $\begin{array}{l}87 \mathrm{de} \\
93 \mathrm{ab} \\
93 \mathrm{ab}\end{array}$ & $\begin{array}{c}90 \mathrm{~g} \\
94 \mathrm{bc} \\
95 \mathrm{cf}\end{array}$ & 90.33 & \multirow{2}{*}{$\begin{array}{c}90.44 \\
\left(0 \mathrm{t} \mathrm{ha}^{-1}\right) \\
\\
94.00 \\
\left(4 \mathrm{t} \mathrm{ha}^{-1}\right)\end{array}$} \\
\hline & 4 & $\begin{array}{l}0 \\
4 \\
8\end{array}$ & $\begin{array}{c}87 \mathrm{de} \\
92 \mathrm{a} \\
92 \mathrm{a}\end{array}$ & $\begin{array}{c}92 \mathrm{a} \\
93 \mathrm{ab} \\
96 \mathrm{fh}\end{array}$ & $\begin{array}{l}93 \mathrm{ab} \\
95 \mathrm{cf} \\
97 \mathrm{~h}\end{array}$ & 93.00 & \\
\hline & 8 & $\begin{array}{l}0 \\
4 \\
8\end{array}$ & $\begin{array}{c}90 \mathrm{~g} \\
93 \mathrm{ab} \\
94 \mathrm{bc}\end{array}$ & $\begin{array}{l}94 \mathrm{bc} \\
100 \mathrm{ij} \\
101 \mathrm{j}\end{array}$ & $\begin{array}{c}95 \mathrm{cf} \\
99 \mathrm{i} \\
105 \mathrm{k}\end{array}$ & 96.78 & $\begin{array}{c}95.67 \\
\left(8 \mathrm{tha}^{-1}\right)\end{array}$ \\
\hline \multicolumn{3}{|c|}{ Sawdust (SD) mean } & 89.89 & 94.33 & 95.89 & & \\
\hline
\end{tabular}

In a row and column, means followed by a common letter are not significantly different at $5 \%$ level by DMRT.

The applications of these amendments alone or in combination were found to have significant ( $\mathrm{p}$ $\leq 0.05)$ positive increase in plant heights for both at moist and saturated conditions. The tallest heights of rice plants ( $99 \mathrm{~cm}$ in moist and $105 \mathrm{~cm}$ in saturated condition) were recorded in the $\mathrm{RH}_{8} \mathrm{RS}_{8} \mathrm{SD}_{8}$ treatment, which received the highest rates of combination of these 3 amendments. The shortest plant heights $(79 \mathrm{~cm}$ in moist, $86 \mathrm{~cm}$ in saturated condition) were recorded in the control condition $\left(\mathrm{RH}_{0} \mathrm{RS}_{0} \mathrm{SD}_{0}\right)$, where no amendment was made. 


\section{Tiller production}

Tiller production of rice was found to be increased by the application of rice hull, rice straw and saw dust, and the effects were observed more pronounced with the highest rates of these treatments, which were found to be distinct with the progress of plant growth. The number of productive tiller was significantly $(\mathrm{p} \leq 0.05)$ higher over control $\left(\mathrm{RH}_{0} \mathrm{RS}_{0} \mathrm{SD}_{0}\right)$ in most of the treatments alone and their combination under both the moist and saturated conditions (Table 4). At maturity, the increment in the number of productive tillers compared to control ranged from 25 to $150 \%$ at moist and 50 to $175 \%$ at saturated conditions, respectively.

Table 4. Comparison of number of productive tillers of rice (BRRI dhan 48) grown in saline soil as influenced by the application of rice hull (RH), rice straw (RS), saw dust (SD) and moisture conditions.

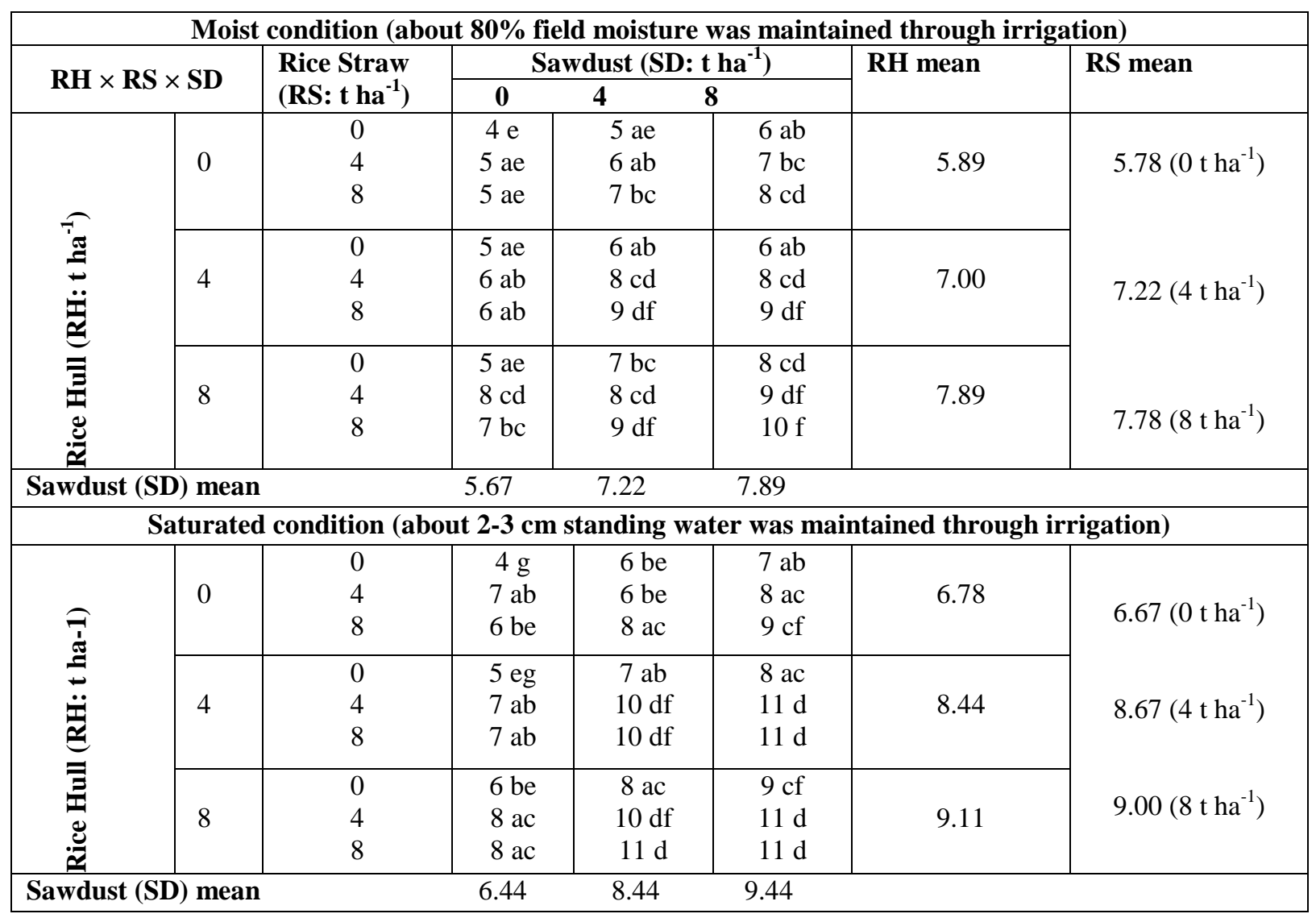

In a row and column, means followed by the same letter are not significantly different at $5 \%$ level by DMRT.

The maximum numbers of productive tillers were recorded in the $\mathrm{RH}_{8} \mathrm{RS}_{8} \mathrm{SD}_{8}$ treatment, and the treatments $\mathrm{RH}_{8} \mathrm{RS}_{8} \mathrm{SD}_{4}, \mathrm{RH}_{8} \mathrm{RS}_{4} \mathrm{SD}_{8}, \mathrm{RH}_{4} \mathrm{RS}_{8} \mathrm{SD}_{8}$ and $\mathrm{RH}_{4} \mathrm{RS}_{8} \mathrm{SD}_{4}$ were ranked second followed by $\mathrm{RH}_{8} \mathrm{RS}_{4} \mathrm{SD}_{4}, \mathrm{RH}_{4} \mathrm{RS}_{4} \mathrm{SD}_{8}, \mathrm{RH}_{4} \mathrm{RS}_{4} \mathrm{SD}_{4}, \mathrm{RH}_{8} \mathrm{RS}_{0} \mathrm{SD}_{8}$ and $\mathrm{RH}_{0} \mathrm{RS}_{8} \mathrm{SD}_{8}$ treatments, respectively at moist condition. Almost the similar trends and effects were observed under saturated soil condition though the numbers of productive tiller were greater than those of moist soil condition. However, the increments in number of productive tillers by the application of these agricultural amendments in the conducted study might be the resultant effect of increased organic matter status which in turn release nutrients gradually as per the requirements of plants grown under saline soil. 


\section{Straw yield}

Data obtained for straw yield at maturity of rice demonstrated that rice hull, rice straw, saw dust and their combined application had significant $(\mathrm{p} \leq 0.05)$ impacts on straw yields (Fig. 1) under both the conditions of soil moistures. The higher straw dry matter yields were obtained under the saturated soil condition compared to moist soil condition regardless of treatments (Fig. 1). Treatments $\mathrm{RH}_{8} \mathrm{RS}_{8} \mathrm{SD}_{8}$ and $\mathrm{RH}_{8} \mathrm{RS}_{8} \mathrm{SD}_{4}$ were ranked first considering the maximum straw yield followed by the treatments $\mathrm{RH}_{8} \mathrm{RS}_{4} \mathrm{SD}_{8}, \mathrm{RH}_{8} \mathrm{RS}_{4} \mathrm{SD}_{4}$ and $\mathrm{RH}_{4} \mathrm{RS}_{8} \mathrm{SD}_{4}$ at the saturated condition of the soil. The effects of the other treatments were found to be increased with their higher rates and combinations. The combination of rice hull, rice straw and sawdust applied each at the rate of $8 \mathrm{t} \mathrm{ha}^{-1}$ under both the conditions of soil moisture were found to be the most effective in increasing straw yield of rice. The results revealed that the rice hull, rice straw and saw dust application alone and in combination were effective for production of straw dry matter. These effects were more pronounced by the combined application of these treatments at their higher rates and the best response was attained at saturated condition through imparting favorable conditions for the growth and yield performance of rice as explained earlier.

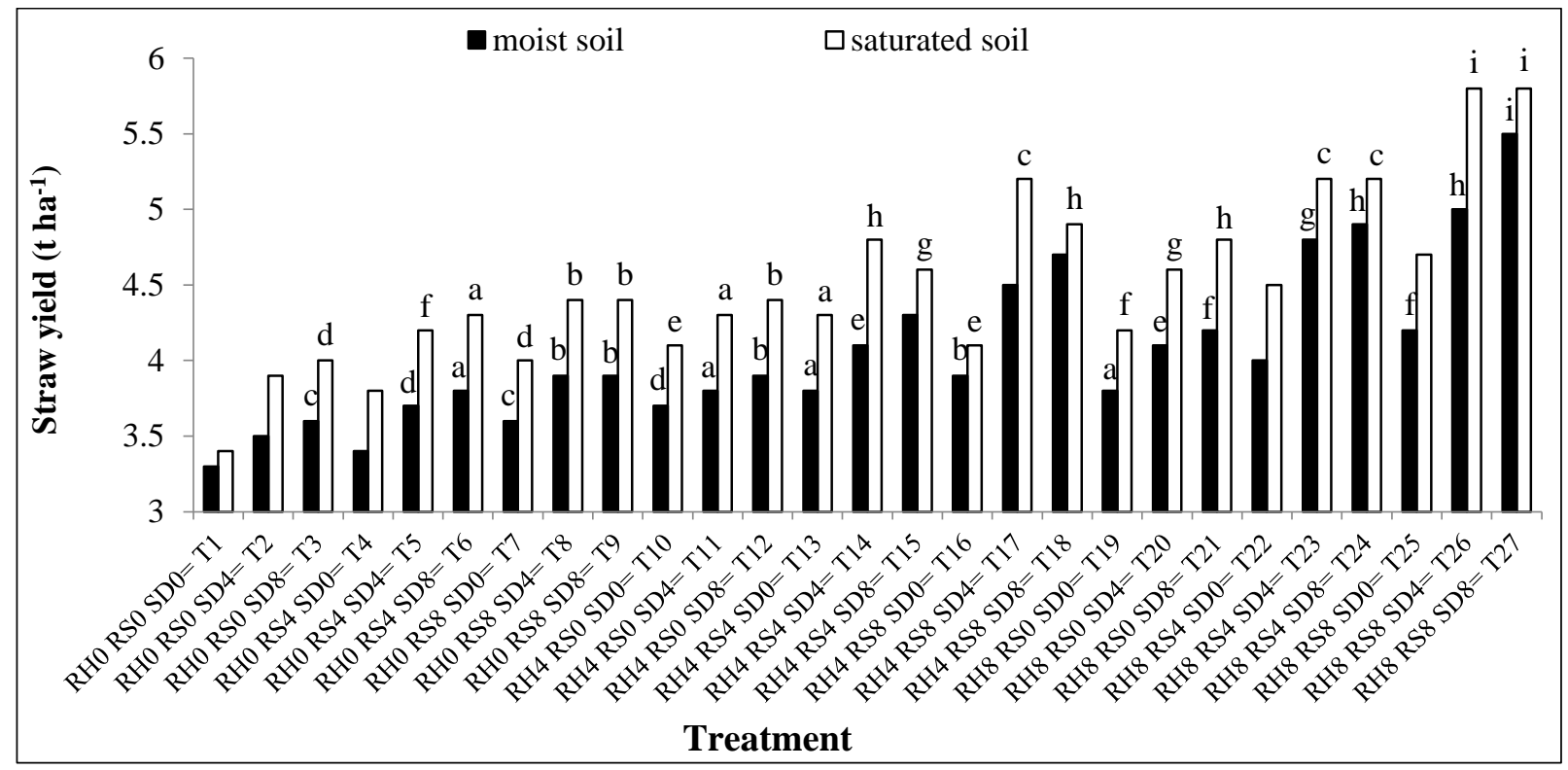

Fig. 1. Straw yield of rice (BRRI dhan 48) grown in saline soil as influenced by the application of rice hull, rice straw, sawdust and moisture conditions.

The results of these 3 amendments could be explained according to the findings of Jong-Myung et al. (2000), who postulated that the air space of sawdust was low (4\%) indicating that aeration could be a problem for container-grown plants in this substrate. However, the electrical conductivity and cation exchange capacity of sawdust were higher than those of the studied organic substrates. ElKeltawi et al. (2012) concluded that sawdust might be better if used in mixtures with other materials to grow plants in closed system.

\section{Grain yield}

The different treatments exerted significant $(\mathrm{p} \leq 0.05)$ positive effects on the grain yield of rice grown in saline soil. The individual effect of rice hull, rice straw and saw dust were positive in increasing the grain yield over control but their combinations were more effective under both 
moisture levels of the soil. But the effects of the treatments were found better in saturated saline soil condition than those obtained from the moist soil condition (Fig. 2). The highest yield $\left(4.4 \mathrm{tha}^{-1}\right)$ was recorded in $\mathrm{RH}_{8} \mathrm{RS}_{8} \mathrm{SD}_{8}$ treatment followed by $\mathrm{RH}_{8} \mathrm{RS}_{8} \mathrm{SD}_{4}$ and $\mathrm{RH}_{8} \mathrm{RS}_{4} \mathrm{SD}_{8}$ at saturated soil condition. These results are partially agreed with the findings of Sarkar et al. (2017) who reported that RS create favorable soil conditions for better rice growth and development. The results are also partially in accordance with earlier findings of Kaniz and Khan (2013) and Iqbal (2016). They reported that the growth and yield of rice grown on saline soils increased significantly with the application of rice hull, gypsum and saw dust. Kaniz and Khan also suggested that the lower dose $(5 \mathrm{t}$ $\left.\mathrm{ha}^{-1}\right)$ was effective but the higher dose $\left(10 \mathrm{tha}^{-1}\right)$ behaved negatively in improving the adverse effect of salinity and yield performance of saline sensitive rice variety.

Results demonstrated that the rice yields from the studied saline soil were increased from 2.7 to $4.4 \mathrm{tha}^{-1}$ due to the application of rice hull, rice straw and saw dust each at the rates of 4 and $8 \mathrm{tha}^{-1}$ under variable moisture conditions, which are encouraging and environmentally sound treatments regarding the reclamation and improvement of saline soils if these amendments are available locally.

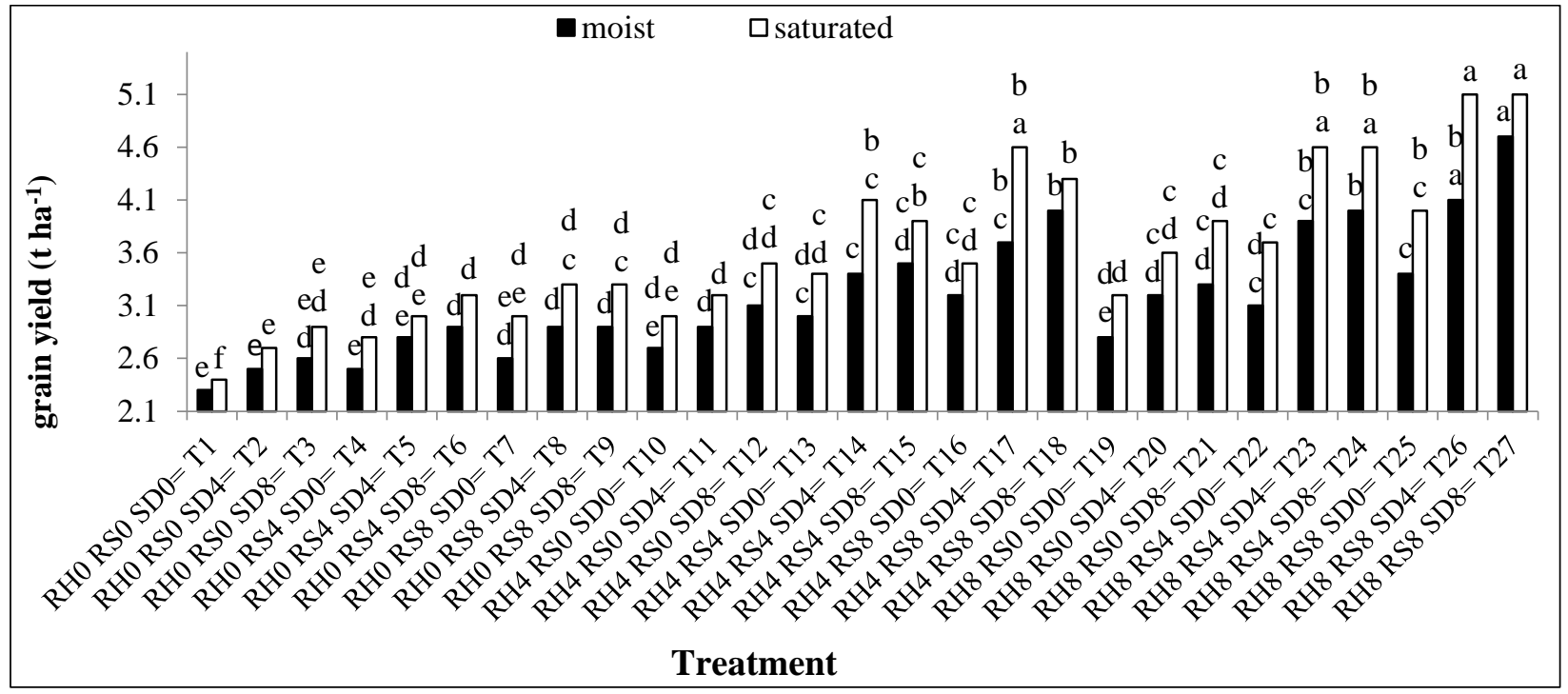

Fig. 2. Grain yield of rice (BRRI dhan 48) grown in saline soil as influenced by the application of rice hull, rice straw, sawdust and moisture conditions.

\section{Harvest index and 1000 grain weight}

For cereal crops, harvest index (HI) is a very good indicator for crop production. Accordingly, the factors associated with and their influences on HI deserve special attention to study this index of yield parameters. The harvest index is the ratio of harvested grain to total shoot dry matter, and this can be used as a measure of reproductive efficiency (Murray-Unkovich and Matthew-Forbes 2010). Harvest index has been shown to be a variable factor in crop production, and in many situations, it is closely associated with water use efficiency and grain yield in cereals (Jianchang-Yang and Jianhua-Zhang 2010).

Table 5 shows the impacts of agricultural amendments such as rice hull, rice straw and sawdust were found for the effective improvement of yield components like harvest index and 1000 grain weight of the studied rice cultivar. The combined application of the amendments exerted more positive results than their individual application. The highest values of these yield components were obtained from the treatment $\mathrm{RH}_{8} \mathrm{RS}_{8} \mathrm{SD}_{8}$ under both moisture levels of the soil. But, at saturated condition these effects were more pronounced than those of the moist level (Table 5). Harvest index 
increased $12.20 \%$ at moist and $14.63 \%$ at saturated soil conditions and the 1000 grain weight also followed the similar trends of effects under both the moisture conditions, where saturated condition ranked first in increase of grain weight like other yield parameters (Table 5).

Table 5. Yield components of rice (BRRI dhan 48) grown in saline soil as influenced by the application of rice hull $(\mathbf{R H})$, rice straw (RS), sawdust (SD) and moisture conditions.

\begin{tabular}{|c|c|c|c|c|c|c|c|}
\hline \multicolumn{2}{|c|}{ Treatment } & \multicolumn{4}{|c|}{ Harvest Index } & \multicolumn{2}{|c|}{1000 grain weight $(\mathrm{g})$} \\
\hline No. & Denotation & $\begin{array}{l}\text { Moist } \\
(\mathbf{8 0 \%})\end{array}$ & $\begin{array}{c}\# I O C \\
(\%)\end{array}$ & $\begin{array}{c}\text { Saturated } \\
(>100 \%)\end{array}$ & $\begin{array}{c}\# I O C \\
(\%)\end{array}$ & $\begin{array}{l}\text { Moist } \\
(\mathbf{8 0 \%})\end{array}$ & $\begin{array}{c}\text { Saturated } \\
(>100 \%)\end{array}$ \\
\hline $\mathrm{T}_{1}$ & $\mathrm{RH}_{0} \mathrm{RS}_{0} \mathrm{SD}_{0}$ & 0.41 & 0 & 0.41 & 0 & $15.13 \mathrm{f}$ & $16.14 \mathrm{e}$ \\
\hline $\mathrm{T}_{2}$ & $\mathrm{RH}_{0} \mathrm{RS}_{0} \mathrm{SD}_{4}$ & 0.42 & 2.44 & 0.41 & 0 & 16.27ef & $16.99 \mathrm{ed}$ \\
\hline $\mathrm{T}_{3}$ & $\mathrm{RH}_{0} \mathrm{RS}_{0} \mathrm{SD}_{8}$ & 0.42 & 2.44 & 0.42 & 2.44 & $16.51 \mathrm{ef}$ & $17.06 \mathrm{ed}$ \\
\hline $\mathrm{T}_{4}$ & $\mathrm{RH}_{0} \mathrm{RS}_{4} \mathrm{SD}_{0}$ & 0.42 & 2.44 & 0.42 & 2.44 & 16.69ef & $17.80 \mathrm{~d}$ \\
\hline $\mathrm{T}_{5}$ & $\mathrm{RH}_{0} \mathrm{RS}_{4} \mathrm{SD}_{4}$ & 0.43 & 4.88 & 0.42 & 2.44 & $17.12 \mathrm{e}$ & $17.96 \mathrm{~d}$ \\
\hline $\mathrm{T}_{6}$ & $\mathrm{RH}_{0} \mathrm{RS}_{4} \mathrm{SD}_{8}$ & 0.43 & 4.88 & 0.43 & 4.88 & $17.24 \mathrm{e}$ & $18.06 \mathrm{~d}$ \\
\hline $\mathrm{T}_{7}$ & $\mathrm{RH}_{0} \mathrm{RS}_{8} \mathrm{SD}_{0}$ & 0.42 & 2.44 & 0.43 & 4.88 & $16.93 \mathrm{ef}$ & $18.21 \mathrm{~d}$ \\
\hline $\mathrm{T}_{8}$ & $\mathrm{RH}_{0} \mathrm{RS}_{8} \mathrm{SD}_{4}$ & 0.43 & 4.88 & 0.43 & 4.88 & $17.27 \mathrm{e}$ & $18.40 \mathrm{~d}$ \\
\hline $\mathrm{T}_{9}$ & $\mathrm{RH}_{0} \mathrm{RS}_{8} \mathrm{SD}_{8}$ & 0.43 & 4.88 & 0.43 & 4.88 & $17.28 \mathrm{e}$ & $18.42 \mathrm{~d}$ \\
\hline $\mathrm{T}_{10}$ & $\mathrm{RH}_{4} \mathrm{RS}_{0} \mathrm{SD}_{0}$ & 0.42 & 2.44 & 0.42 & 2.44 & 16.70ef & $17.36 \mathrm{de}$ \\
\hline $\mathrm{T}_{11}$ & $\mathrm{RH}_{4} \mathrm{RS}_{0} \mathrm{SD}_{4}$ & 0.44 & 7.32 & 0.43 & 4.88 & $18.08 \mathrm{ed}$ & $18.15 \mathrm{~d}$ \\
\hline $\mathrm{T}_{12}$ & $\mathrm{RH}_{4} \mathrm{RS}_{0} \mathrm{SD}_{8}$ & 0.44 & 7.32 & 0.44 & 7.32 & $18.38 \mathrm{de}$ & $19.88 \mathrm{~cd}$ \\
\hline $\mathrm{T}_{13}$ & $\mathrm{RH}_{4} \mathrm{RS}_{4} \mathrm{SD}_{0}$ & 0.44 & 7.32 & 0.44 & 7.32 & $18.20 \mathrm{de}$ & $19.43 \mathrm{~cd}$ \\
\hline $\mathrm{T}_{14}$ & $\mathrm{RH}_{4} \mathrm{RS}_{4} \mathrm{SD}_{4}$ & 0.45 & 9.76 & 0.46 & 12.20 & $21.41 \mathrm{cb}$ & $22.38 \mathrm{~b}$ \\
\hline $\mathrm{T}_{15}$ & $\mathrm{RH}_{4} \mathrm{RS}_{4} \mathrm{SD}_{8}$ & 0.45 & 9.76 & 0.46 & 12.20 & $21.49 \mathrm{cb}$ & $22.90 \mathrm{~b}$ \\
\hline $\mathrm{T}_{16}$ & $\mathrm{RH}_{4} \mathrm{RS}_{8} \mathrm{SD}_{0}$ & 0.45 & 9.76 & 0.46 & 12.20 & $21.80 \mathrm{bc}$ & $22.39 \mathrm{~b}$ \\
\hline $\mathrm{T}_{17}$ & $\mathrm{RH}_{4} \mathrm{RS}_{8} \mathrm{SD}_{4}$ & 0.45 & 9.76 & 0.47 & 14.63 & $22.65 \mathrm{~b}$ & $24.20 \mathrm{ab}$ \\
\hline $\mathrm{T}_{18}$ & $\mathrm{RH}_{4} \mathrm{RS}_{8} \mathrm{SD}_{8}$ & 0.46 & 12.20 & 0.47 & 14.63 & $23.49 \mathrm{ba}$ & $24.40 \mathrm{ab}$ \\
\hline $\mathrm{T}_{19}$ & $\mathrm{RH}_{8} \mathrm{RS}_{0} \mathrm{SD}_{0}$ & 0.42 & 2.44 & 0.43 & 4.88 & $16.87 \mathrm{e}$ & $18.09 \mathrm{~d}$ \\
\hline $\mathrm{T}_{20}$ & $\mathrm{RH}_{8} \mathrm{RS}_{0} \mathrm{SD}_{4}$ & 0.44 & 7.32 & 0.44 & 7.32 & $18.15 \mathrm{ed}$ & $19.46 \mathrm{dc}$ \\
\hline $\mathrm{T}_{21}$ & $\mathrm{RH}_{8} \mathrm{RS}_{0} \mathrm{SD}_{8}$ & 0.44 & 7.32 & 0.45 & 9.76 & $19.25 \mathrm{dc}$ & $20.73 \mathrm{c}$ \\
\hline $\mathrm{T}_{22}$ & $\mathrm{RH}_{8} \mathrm{RS}_{4} \mathrm{SD}_{0}$ & 0.44 & 7.32 & 0.45 & 9.76 & $19.04 \mathrm{~d}$ & $20.14 \mathrm{c}$ \\
\hline $\mathrm{T}_{23}$ & $\mathrm{RH}_{8} \mathrm{RS}_{4} \mathrm{SD}_{4}$ & 0.45 & 9.76 & 0.47 & 14.63 & $22.90 \mathrm{ba}$ & $25.13 \mathrm{a}$ \\
\hline $\mathrm{T}_{24}$ & $\mathrm{RH}_{8} \mathrm{RS}_{4} \mathrm{SD}_{8}$ & 0.45 & 9.76 & 0.47 & 14.63 & $22.95 \mathrm{ba}$ & $25.30 \mathrm{a}$ \\
\hline $\mathrm{T}_{25}$ & $\mathrm{RH}_{8} \mathrm{RS}_{8} \mathrm{SD}_{0}$ & 0.45 & 9.76 & 0.46 & 12.20 & $20.70 \mathrm{c}$ & $22.23 \mathrm{ba}$ \\
\hline $\mathrm{T}_{26}$ & $\mathrm{RH}_{8} \mathrm{RS}_{8} \mathrm{SD}_{4}$ & 0.45 & 9.76 & 0.47 & 14.63 & $22.54 \mathrm{ba}$ & $24.38 \mathrm{ab}$ \\
\hline $\mathrm{T}_{27}$ & $\mathrm{RH}_{8} \mathrm{RS}_{8} \mathrm{SD}_{8}$ & 0.46 & 12.20 & 0.47 & 14.63 & $24.43 \mathrm{a}$ & $25.49 \mathrm{a}$ \\
\hline
\end{tabular}

The growth, yield and yield components of rice plants in the studied saline soil were found to be improved by the application of agricultural amendments like rice hull, rice straw and sawdust at the rates of 0,4 and $8 \mathrm{t} \mathrm{ha}^{-1}$ alone and in combination under variable soil moisture levels. In many studies, recycling of rice straw is reported to increase the organic carbon and nutrient contents in soil (Misra et al. 1996, Eagle et al. 2000). Rice hull improved water holding capacity of soil. It also increased organic matter content of the soil and subsequently increased crop yield (Begum and Khan 2013). The application of rice hull and sawdust increased organic matter in the soil which in turn increased nitrogen to the soil and also increased nitrogen content in plant tissues (Kaniz and Khan 2013). Water movement is one of the major problems in saline soils due to the adverse effects of salinity on soil physical properties which may improve by the indigenous organic amendments like rice hull, rice straw and sawdust. Accordingly, these agricultural amendments might help in improving the physical, chemical and physico-chemical properties of the soils, specially the improvement of physical condition of saline soil is utmost need regarding reclamation and 
improvement of saline soils in relation to crop production. In this context, the applied agricultural amendments deserve attention to use under variable field and climatic conditions before final recommendation to farmers level. These practices will not only improve the saline soils but also will increase the rice production which ultimately could contribute to the national economy and food security.

\section{ACKNOWLEDGEMENTS}

The study was carried out under the project entitled 'Assessment of Impacts of Climate Change on Soil Health and Food Security, and Adaptation of Climate-smart Agriculture in Most Adversely Affected Areas of Bangladesh' funded (2017-2018) by BCCT, MoEFCC, Government of the Peoples' Republic of Bangladesh. We are also grateful to the Ministry of Science and Technology for providing NST fellowship for the first author.

\section{REFERENCES}

Ali, M. E., M. R. Islam and M. Jahiruddin. 2009. Effect of integrated use of organic manures with inorganic fertilizers in the rice-rice cropping system and its impact on soil health. Bangladesh Journal of Agricultural Research. 34: 81-90.

Begum, M. and H. R. Khan. 2013. Influence of gypsum, rice-hull and different levels of saline water irrigation on water soluble cations and organic matter content in different saline soils in response to wheat. Int. J. Res. Appl. Nat. Soc. Sci. 1: 15-22.

Black, C. A. (ed.). 1965. Methods of soil analysis. Part 2. Am Soc. Agron. Inst. Publ., Madison, WI., pp. 894-1372.

Byous, E. W., J. E. Williams, G. E. Jonesa, W. R. Horwath and C. Kessel. 2004. Nutrient requirements of rice with alternative straw management. Better Crops. 36: 6-11.

Chapman, H. D. 1965. Cation exchange capacity. In: C. A. Black (ed). Methods of soil analysis. Part 2. Am. Soc. Agron. Inst. Publ., Madison, WI., pp. 891-900.

Conrad, R. 2002. Control of microbial methane production in wetland rice fields. Nut. Cyc. in Agro. 64: 59-69.

Dobermann, A. and T. H. Fairhurst. 2002. Rice Straw Management. In: Better Crops International, Special supplement publication: Rice Production. Vol. 16. Potash and Phosphate Institute of Canada.

Eagle, A. J., J. A. Bird, W. R. Horwaath, B. A. Linquist, S. M. Brouder, J. E. Hill and C. V. Kessel. 2000. Rice yield and nitrogen utilization efficiency under alternative straw management practices. Agron. J. 92: 1096-1103.

El-Keltawi, N., A. Tawfik, G. Hassan and O. Ibrahim. 2012. Compost From Rice Straw and Sawdust as Growing Media for Pot Plants. Assiut. J. Agric. Sci. 43: 66-80.

Gaihre, Y. K., R. Wassmann and G. Villegas-Pangga. 2013. Impact of elevated temperatures on greenhouse gas emissions in rice systems: interaction with straw incorporation studied in a growth chamber experiment. Plant Soil. 373: 857-875.

Iqbal, T. 2016. Rice straw amendment ameliorates harmful effect of salinity and increases nitrogen availability in a saline paddy soil. J. Saudi Soc. Agricul. Sci. (In Press). 
Jackson, M. L. 1973. Soil Chemical Analysis, Prentice Hall of India Pvt. Ltd., New Delhi. India., pp. 36-196.

Jianchang-Yang and Jianhua-Zhang. 2010. Crop management techniques to enhance harvest index in rice. J. Exp. Bot. 61(12): 3177-3189.

Jong-Myung, C. J., C. Hae-Joon and C. Jong-Seung. 2000. Physico-chemical properties of organic and inorganic materials used as container media. Korean J. Hort. Sci. Tech. 18: 529-535.

Kabir, M. S., M. U. Salam, A. Chowdhury, N. M.F. Rahman, K. M. Iftekharuddaula, M. S. Rahman, and J. K. Biswas. 2015. Rice vision for Bangladesh: 2050 and beyond. Bangladesh Rice J. 19(2): $1-18$.

Kaniz, F. and H. R. Khan. 2013. Reclamation of saline soil using gypsum, rice hull and sawdust in relation to rice production. J. Adv. Sci. Res. 4(3): 1-5.

Khan, H. R., S. M. Kabir and M. M. A. Bhuiyan. 2016. Effects of selected treatments and techniques for the reclamation and improvement of Cheringa acid sulfate soil under rice production in the coastal plain of Cox's Bazar. J. Asiat. Soc. Bangladesh Sci. 42(1): 29-40.

Misra, R. D., V. K. Gupta and D. S. Pandey. 1996. Management crop residues in rice. Int. Rice Res. Notes. 21: 71-72.

Murray-Unkovich and Matthew-Forbes. 2010. Variability in harvest index of grain crops and potential significance for carbon accounting. Adv. Agron 105: 173-219.

Nelson, D. W. and L. E. Sommers. 1982. Total carbon, organic carbon and organic matter. In: A. L. Page (ed.). Methods of Soil Analysis. Part 2. Am. Soc. Agron., Publ. Madison, WI, USA., pp. 539-579.

Olsen, S. R., C. V. Cale, F. S. Watanabe and L. A. Dean. 1954. Estimation of available phosphorus in soils by extraction with sodium bicarbonate. USDA Circ. 939, Washington, USA.

Piper, C. S. 1966. Soil and Plant Analysis. Hano Publ. Bombay, India.

Ponnamperuma, F. N. 1984. Straw as source of nutrients forwetland rice. In: S. Banta and C. V. Mendoza (eds.). Organicmatter and rice. International Rice Research Institute. Manila., pp. 117136.

Pratt P. F. 1965. Methods of Soil Analysis. Am. Soc. Agron. Madison, Wisconsin, USA. 1022 pp.

Richards, L.A. 1954. Diagnosis and improvement of saline and alkali soils. In: USDA Handbook No. 60. US Govt. Print. Office, Washington, USA., pp. 84-156.

Saha, P. K., M. A. M. Miah, A. T. M. S. Hossain, F. Rahmanand M. A. Saleque. 2009. Contribution of rice straw to potassium supply in rice-fallow-rice cropping pattern. Bangladesh J. Agricul. Res. 34: 633-643.

Sarkar, M. I. U., M. M. Rahman, G. K. M. M. Rahman, U. A. Naherand M. N. Ahmed. 2016. Soil test based inorganic fertilizer and integrated plant nutrition system for rice (Oryza sativa L.) cultivation in inceptisols of Bangladesh. The Agriculturists. 14: 33-42.

Sarkar, M. I. U., M. N. Islam, A. Jahan, A. Islam and J. C. Biswas. 2017. Rice straw as a source of potassium for wetland rice cultivation. Geol. Ecol. Landscapes. 1(3): 184-189. 